\title{
Translating Metaphor and Simile from Persian to English: A Case Study of Khayyam's Quatrains
}

\author{
Morteza Zohdi \\ English Language Department, University of Applied Science \& Technology, Center18, Tehran, Iran \\ Email: zohdilinguistics@yahoo.com \\ Ali Asghar Rostami Abou Saeedi \\ English Department, Faculty of Arts,University of Sistan \& Baluchestan, Zahedan, Iran \\ Email: rostamiabu110@yahoo.com
}

\begin{abstract}
Metaphor and simile are two figures of speech which make comparison between two things. These two figures of speech are widely used by writers and poets in their literary works and Persian poets are no exception. Metaphor and simile often create problem for translators. These problems are even more complicated in poetry due to its compactness and its obligation to preserve the sound effects. This research intends to identify the most accurate translation made of the Rubaiyat of Omar Khayyam in translating its metaphors and similes. Khayyam is a well-known poet in the west and certainly the most famous one. This fame is due to the translation of his Rubaiyat by the Victorian poet Edward FitzGerald. But FitzGerald has not rendered an accurate translation and has done a more or less a free translation. In his translation, many of the verses are paraphrased, and some of them cannot be confidently traced to any of Khayyam's quatrains at all. Other translators also have translated Rubaiyat. This study investigates two translations of Rubaiyat (i.e. FitzGerald and Arberry) with regard to similes and metaphors.
\end{abstract}

Index Terms - Khayam, quaterian, rubaiyat, metaphor, simile

\section{INTRODUCTION}

Translating figures of speech due to cultural and linguistic differences is a challenging task. This challenge multiplies when the translator has to deal with metaphors, and to a lesser degree, similes. It is even more difficult in poetry, because in poetry the translator has little options due to the sound devices and compactness of poetry. Above all, there is a great cultural gap between English and Persian, which makes it again more difficult. Even translation scholars admit the difficulty; Newmark (1981, p. 105) says "Whilst the central problem of translation is the overall choice of a translation method for a text, the most important particular problem is the translation of metaphor." Therefore, in this research the researcher intends to find out which strategies the translator has used in dealing with similes and metaphors in translating Khayyam's quatrain and also to see which translator has been more successful in transferring connotations and meanings of similes and metaphors.

The result of this study can be useful to the trainee translators and also to the researchers in the field of translation studies. The trainee translators can benefit from this research as it provides them with the aspects ignored by translators in dealing with simile and metaphor, especially simile and metaphor in poetry .Therefore the trainee translators can choose better options while translating simile and metaphor. Also researchers can benefit from the result of this research as it reveals the strategies adopted by translators in translating simile and metaphor and the aspects of the message which have not been adequately translated. Therefore researchers can use these results to devise a better strategy for translating simile and metaphor. Furthermore, one of the other goals of this research is to attract the attention of translators toward the issue of the problems on the way of accurate translation of Persian metaphor and simile into English as well as connecting linguistic findings of translation studies to the practice of translation.

\section{A. Translation Process and the Act of Translating}

Catford (1965, p. 20) defines translation as: "the replacement of textual material in one language (SL) by equivalent textual material in another language (TL)".

By translation here we mean the act or the process of translating. "Translation process" may be used to designate a variety of phenomena, from the cognitive processes activated during translating, both conscious and unconscious, to the more "physical" process which begins when a client contacts a translation bureau and ends when that person declares satisfaction with the product produced as the final result of the initial inquiry. In translation practice, of course, the cognitive aspects are activated under the influence of the physical aspects, and their interdependency for either research or educational purposes might be a bad idea. In his discussion of translation competence, Kiraly (1995, p. 139) presents his "doubly articulated view of translation processes: from the translator's perspective, looking outward toward the social situation in which professional translation occurs, and looking inward toward the mental processes going on in 
the individual translator's mind during the production of a translation". The two aspects are inseparable and, while particular studies will naturally tend to focus on one of these perspectives, it is important not to lose sight of the other.

Even when we decide to examine only the cognitive aspects, the problem of delineating the "translation process" is not over. House (2000, p. 150) points out that, in using the term "process of translation", "we must keep in mind that we are dealing here not with an isolable process but rather with a set of processes, a complex series of problem-solving and decision-making processes". She goes on to say that we can look upon the "process" as "any number of operations" performed by a translator while converting a source text into a translation text. Attempts have been made to isolate the different sub-processes that make up the process of translation.

According to House (2000), the selection and the sequencing of the various operations that make up the translation process is conditioned by "semantic, pragmatic, situation-specific and culture-specific constraints operating on two 'levels' - that of the source and that of the target language" and also by "the emergent translation text itself both in its physical realization and its on-line cognitive representation" (p.150-151).

Furthermore, Tirkkonen-Condit (2000, p. 123) claims that "no two processes are the same, even though the task is the same". Wilss (1996, p. 42) voices a similar opinion when he says that "translation is an activity that varies as we pass from one translator to the next, from one ST to the next, and from one TT readership to the next". Séguinot (1997, pp. 104-105) elaborates this point by saying that:

Different text types require different approaches; different people can translate the same text in different ways [...]. Different levels of competence, familiarity with the material to be translated, as well as different interpretations of the nature of the assignment will lead to differences in processes and in the results. Even more specifically, there is potential for variation within the individual, that is, the possibility of there being different pathways to access language, interpret it, and produce it.

Séguinot explains the variability by describing translation as a "toolbox" rather than algorithmic skill. A toolbox skill implies that there is a variety of choices, which depend on a number of things, including "the nature of the assignment, the functions of the text, the translating ideology held by the individual or the institution initiating the request, as well as the pragmatics of the translating situation" (p.109).

\section{B. Simile}

Simile is much less investigated than metaphor therefore there is not much work about simile. Newmark (1981, p. 88) believes that similes "must normally be transferred in any type of text, but in sci-tech texts the simile should be culturally familiar to the TL reader". And he also believes since the whole point of a simile, like that of metaphor, is to produce an accurate description, it is pointless to tone it down with a smoother collocation. Larson (1984, p. 246-247) has discussed translating simile together with metaphor and believes that metaphor and simile are grammatical forms which represent two propositions in the semantic structure and she believes it can be very helpful to the translator to analyze it and find the two propositioned which are the semantic structure behind it. She believes that a metaphor or simile has four parts which are: topic, image, point of similarity and nonfigurative equivalent.

She believes in English simile is composed of two propositions and it has four parts which are:

1. Topic - the topic of the first proposition (nonfigurative), i.e. the thing really being talked about.

2. Image - the topic of the second proposition (figurative), i.e. what is being compared with.

3. Point of similarity - found in the comments of both the propositioned involved or the comment of the EVENT proposition which has the image as topic.

4. Nonfigurative equivalent - when the proposition containing the topic is an EVENT proposition, the COMMENT is the nonfigurative equivalent. (p. 247).

Larson also mentions that only when propositions and four parts of the simile have been identified, can an adequate translation be made into a second language.

She believes (p.254) a metaphor may be translated in five ways as follow (a simile would follow steps 3, 4, and 5):

1. The metaphor may be kept if the receptor language permits

2. A metaphor may be translated as a simile

3. A metaphor of the receptor language which has the same meaning may be substituted

4. The metaphor may be kept and the meaning explained (that is, the topic/or point of similarity be added)

The meaning of the metaphor may be translated without keeping the metaphorical imagery

\section{Metaphor}

According to Abrams (1999) in a metaphor, a word or expression that in literal usage denotes one kind of thing is applied to a distinctly different kind of thing, without asserting a comparison.

Metaphor brings forth the unique human ability to create and transmit ideas through the manipulation of language. metaphor is as old as the history of literature is. It is one of the main characters in the play of literature, indeed. For ages, it has been translated as a part of a literary or non-literary text and nobody had talked about its nature in translation, or proposed some procedures on how it can be translated before Newmark (1981).

\section{Rubaiyat}


Rubaiyat is the plural of Rubai. Rubai is a verse, a kind of quatrain rhymed aaxa. Rubai is known in west because of Rubaiyat of Omar Khayyam by FitzGerald. It is a free translation of Persian version of Rubaiyat. The historical Omar Khayyam (1048-1131), a Persian mathematician, is hardly one of the great poets of the Persian tradition. At the first when it was published, Rubaiyat of Omar Khayyam didn't sell well. As Bloom (2004, p. 1) says.

FitzGerald's first Rubáiyát appeared in 1859, and would have vanished, unread and forgotten, except that a copy reached Dante Gabriel Rossetti, poet-painter and leader of the circle of Pre-Raphaelites. Rossetti indubitably must have recognized and enjoyed the Tennysonian coloring of the poem.

A decade before FitzGerald's death Rubaiyat became popular and brought him fame. And as Zare-Behtash (1994) remarks "Although Rubaiyat was unnoticed by the mid-Victorian English public, once it was noticed, it was never allowed to fall into neglect again" (p.205), and also Karlin (2009) says:

In the early twentieth century the poem was spoken of as one of the two or three best-known in the English-speaking world; ominously perhaps, it was also spoken of as the poem you would find on the shelves of people who knew no other poetry (p.xii).

FitzGerald has changed many of the poems into new poems and in some instances he has mixed two or three Rubai and created one. Some call this adaptation and not translation at all.

Though FitzGerald had other translations but only his translation of Rubaiyat made him famous. Critics have different views about the success of Rubaiyat. Some believe the reason for the popularity of Rubaiyat is due to its theme and the hedonistic philosophy behind it.

Other translators have also translated Rubaiyat of Khayyam like Arberry, Edward Heron-Allen, Omar Alishah and Robert Graves.

\section{METHODOLOGY}

\section{A. Material}

The material for this research is the Persian text of Rubaiyat and two English translations, one by FitzGerald and the other by Arberry.

\section{B. Procedures}

First the metaphors and similes will be identified in the Persian text then the corresponding translations will be identified and at last based on Larson (1984) the strategy employed by the translators will be identified

According to Larson (1984, p. 254) a metaphor may be translated in five ways as follow (a simile would follow steps 3,4 , and 5):

1. The metaphor may be kept if the receptor language permits

2. A metaphor may be translated as a simile

3. A metaphor of the receptor language which has the same meaning may be substituted

4. The metaphor may be kept and the meaning explained (that is, the topic/or point of similarity be added)

5. The meaning of the metaphor may be translated without keeping the metaphorical imagery

There may be other strategies used by translators, which are not mention by Larson. Those strategies too will be identified.

\section{Data Analysis}

From the eighty three Rubais, thirty-five containing either simile or metaphor or both and translated by both Arberry and FitzGerald were found. Nine strategies employed by the translators in translating the metaphors were found.

Abbreviations:

FT $=$ Fitzgerald's translation.

AT $=$ Arberry's translation

Strategy for metaphor = strategy employed by the translator for translating metaphor

Strategy for simile $=$ strategy employed by the translator for translating simile

khorshid kamande sobh bar bām fekand

keykhosrow rū ze bādeh dar jām fekand

mey khor ke monadi sahar khizān

āvāze oshrebü dar ayyām fekand

Metaphor1: khorshid kamande sobh bār bām fekand

Literal translation: the sun cast the noose of morning on the roof

Meaning: sun came up and it became morning

Metaphor 2: monadie sahar khizān

Literal translation: harbinger of early risers

Meaning: the sun

(FT):

Awake! For Morning in the Bowl of Night

has flung the Stone that puts the Stars to Flight: 
And Lo! The Hunter of the East has caught

The Sultan's Turret in a Noose of Light

Strategy for metaphor 1: translated with two metaphors in the last couplet which has also retained the meaning

Strategy for metaphor 2: a new metaphor which has changed the meaning

(AT):

The sun has cast the noose of morn

Athwart the roof-top of the world;

The emperor of the day has hurled

His bed, our goblet to adorn

Drink wine: for at the first dawn's rays

The proclamation of desire

Rang through the universe entire,

And bade men drink through all days.

Strategy for metaphor 1: literal translation of the metaphor

Strategy for metaphor 2: the meaning of the metaphor has been conveyed without retaining the metaphor ānān ke mohite fazl-o ādāb shodand

dar jam'e kamal sham'e ashāb shodand

rah zin shabe tārik nabordand borūn

goftand fesaneh'i-o dar khāb shodand

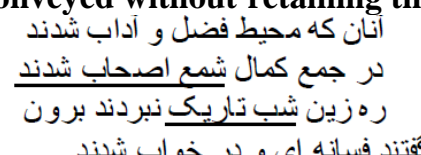

Metaphor 1: sham'e ashāb shodand

Literal translation: became the candle of friends

Meaning: became the guide

Metaphor 2: shabe tārik

Literal translation: dark night

Meaning: mystery of creation and death

Metaphor 3: dar khab shodand

Literal translation: fell asleep

Meaning: died

(FT):

Then to the rolling Heav'n itself I cried,

Asking, "What Lamp had Destiny to guide

Her little Children stumbling in the Dark?"

And--"A blind understanding!" Heav'n replied.

Strategy for metaphor 1: a new metaphor which has changed the meaning

Strategy for metaphor 2: literal translation

Strategy for metaphor 3: omission

(AT):

They who encompassed all high wit

And of fine words the mastery bore,

Who in discovery of deep lore

A lantern for their fellows lit:

Those never won to find a way

Out of the darkness of our night:

They had their legend to recite,

And in endless slumber lay

Strategy for metaphor 1: metaphor has been translated with a new metaphor with the same meaning

Strategy for metaphor 2: literal translation

Strategy for metaphor 3: metaphor has been translated with a new metaphor with the same meaning jāmist ke aghlāfarin mizanadash

sad būseh ze mehr bar jabin mizanadash

in kū zegar-e dahr chenin jāme lat if

misāzado bāz zamin mizanadash

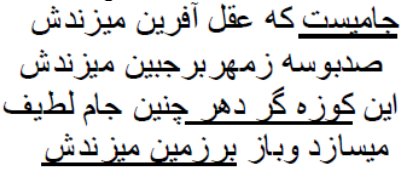

Metaphor 1: jāmist

Literal translation: a bowl

Meaning: human

Metaphor 2: kūzegar-e dahr

Literal translation: potter of age

Meaning: time 
Metaphor 3: bar zamin mizanadash

Literal translation: throws it to the ground

Meaning: kills him

(FT):

That ev'n my buried Ashes such a Snare

Of Perfume shall fling up into the Air,

As not a True Believer passing by

But shall be overtaken unaware.

This Rubai is wholly a new poem and is not a translation

Strategy for metaphor 1: omission

Strategy for metaphor 2: omission

Strategy for metaphor 3: omission

(AT):

Riddle me this; a bowl I know

Which Reason doth high praise allow,

And in affection on its brow

A hundred kisses doth bestow.

Yet time, the fickle potter, who

So skillfully designed a cup

So fragile, loves to lift it up

And dash it to the earth anew.

Strategy for metaphor 1: literal translation

Strategy for metaphor 2: literal translation with addition of meaning

Strategy for metaphor 3: literal translation

in kohne rebat ra ke ālamnām ast

vārāmgahe ablaghe sobh-o shām ast

bazmist ke vāmāndeh sad Jamshid ast

qasrist ke tekye gāhe sad Bahrāmast

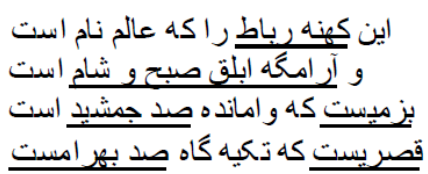

Metaphor 1: kohne rebat

Literal translation: old caravanserai

Meaning: the world

Metaphor 2: ārāmgahe ablagh e sobh o shām

Literal translation: pied resting place of morning and night

Meaning: place of day and night, place of sunrise and sunset

Metaphor 3: bazmi

Literal translation: a feast

Meaning : the world

Metaphor 4: sad Jamshid

Literal translation: a hundred Jamshid

Meaning: many powerful men, many kings

Metaphor 5: qasri

Literal translation: a palace

Meaning: the world

Metaphor 6: sad Bahrām

Literal translation: a hundred Bahrām

Meaning: many powerful men, many kings

(FT):

Think, in this batter'd Caravanserai

Whose Doorways are alternate Night and Day,

How Sultan after Sultan with his Pomp

Abode his Hour or two, and went his way.

Strategy for metaphor 1: literal translation

Strategy for metaphor 2: the meaning of the metaphor has been translated without retaining the metaphor

Strategy for metaphor 3: omission

Strategy for metaphor 4: the meaning of the metaphor has been translated without retaining the metaphor

Strategy for metaphor 5: omission

Strategy for metaphor 6: the meaning of the metaphor has been translated without retaining the metaphor (AT):

This ancient hostelry, which those

May call the World who have the knack, 
A stable is where the poor hack

Of dawn and sunset takes repose

Here Jamshid once high revel kept

But know the feast is bare of him:

Bahram here hunted at his whim,

And here at last forever slept.

Strategy for metaphor 1: literal translation

Strategy for metaphor 2: literal translation

Strategy for metaphor 3: literal translation

Strategy for metaphor 4: literal translation

Strategy for metaphor 5: the meaning of the metaphor has been translated without retaining the metaphor

Strategy for metaphor 6: literal translation

ey dust biā tā ghame fardā nakhorim

vin yek dame o mr ghanimat shemorim

fardā ke az in deyr kohan dar gozarim

bā haft hezār sālegan hamsafarim

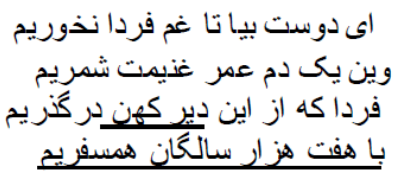

Metaphor 1: deire kohan

Literal translation: ancient monastery

Meaning: world

Metaphor 2: bā haft hezār sālegan hamsafarim

Literal translation: be companion with seven thousand years old people

Meaning: be with those who have died long ago

(FT):

Ah! my Beloved, fill the Cup that clears

To-day of past Regrets and future Fears

To-morrow?--Why, To-morrow I may be

Myself with Yesterday's Sev'n Thousand Years.

Strategy for metaphor 1: omission

Strategy for metaphor 2: literal translation

(AT):

Come, let us not consume with care

For what to-morrow may portend,

But let us count for gain, my friend,

The ready moment that we share.

For in the morn when we are sped

From earth's most ancient hostelry,

We join the immortal company

Of those ten thousand ages dead.

Strategy for metaphor 1: literal translation

Strategy for metaphor 2: literal translation with addition of meaning

afsūs ke nāmehe javāni tay shod

vān tāze bahār zendegāni day shod

ān morghe tarab ke nāme oū būd shabāb

faryād ke nadānam kay āmad kay shod

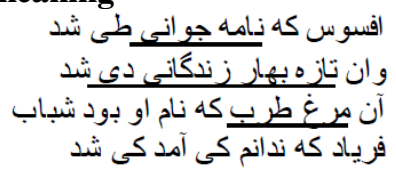

Metaphor 1: nāmehe javāni

Literal translation: book of youth

Meaning: years of being youth

Metaphor 2: tāze bahār zendegāni

Literal translation: early spring of life

Meaning: youth

Metaphor 3: day shod

Literal translation became day(the first month of winter in Iranian calendar)

Meaning: became old

Metaphor 4: morghe tarab

Literal translation: bird of happiness

Meaning: youth

(FT):

Alas, that Spring should vanish with the Rose!

That Youth's sweet-scented Manuscript should close! 
The Nightingale that in the Branches sang,

Ah, whence, and whither flown again, who knows!

Strategy for metaphor 1: literal translation

Strategy for metaphor 2:literal translation

Strategy for metaphor 3: literal translation

Strategy for metaphor 4: the meaning has been conveyed without retaining the metaphor

(AT):

Alas, that at the last must close

The tender tale of boyhood's day,

And life's delightful fragile May

Lie buried in December's snows.

I can not tell, alas, in truth

How ever dwelt among us men

How ever fluttered from our ken

That sweet, elusive song bird, youth.

Strategy for metaphor 1: literal translation with addition of meaning

Strategy for metaphor 2: metaphor has been translated with a new metaphor with the same meaning

Strategy for metaphor 3: metaphor has been translated with a new metaphor with the same meaning

Strategy for metaphor 4: literal translation

zān $\mathrm{p}$ ish ke bar shabikhūn ārand

farmāy ke ta bādeh golgūn ārand

to zar nei ghāfel nādān ke to rā

dar khāk nahand o bāz birūn ārand

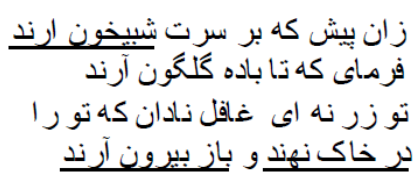

Metaphor 1: shabikhūn ārand

Literal translation: raid you

Meaning: die

Metaphor 2: dar khāk nahand

Literal translation: put into earth

Meaning: bury after death

Metaphor 3: bāz birūn ārand

Literal translation: dig up

Meaning: resurrect

(FT):

And those who husbanded the Golden Grain,

And those who flung it to the Winds like Rain,

Alike to no such aureate Earth are turn'd

As, buried once, Men want dug up again.

Strategy for metaphor 1: omission

Strategy for metaphor 2: translation of the meaning without retaining the metaphor

Strategy for metaphor 3: literal translation

(AT):

Now, in this hour ere night descend

And griefs assail and slay the soul,

Bid them bring forth the crimson bowl

and pour the wine, beloved friend.

Think not, my foolish, silly swain,

Thou art as gold, that on a day

Men should commit thee to cold clay

Thereafter to bring out again

Strategy for metaphor 1: metaphor has been translated with a new metaphor with the same meaning Strategy for metaphor 2: metaphor has been translated with a new metaphor with the same meaning Strategy for metaphor 3: literal translation

gūyand kasān behesht bā hūr khosh ast

man migūyam ke āb angūr khosh ast

in naghd begiro dast azān nesiy'e bedār

kāwāze dohol shenidan az dūr khoshast

Metaphor1: āb angūr

Literal translation: grape juice

Meaning: wine

Metaphor 2: naghd

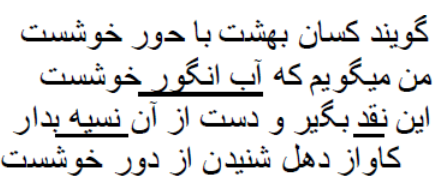

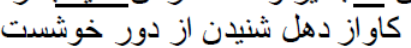


Literal translation: cash

Meaning: worldly and available pleasures

Metaphor 3: nesiy'e

Literal translation: credit

Meaning: promised pleasures in heaven

(FT):

How sweet is mortal Sovranty!"--think some:

Others--"How blest the Paradise to come!"

$\mathrm{Ah}$, take the Cash in hand and waive the Rest;

Oh, the brave Music of a distant Drum!

Strategy for metaphor 1: meaning has been translated without retaining the metaphor

Strategy for metaphor 2: literal translation

Strategy for metaphor 3: the meaning has been translated without retaining the metaphor

(AT):

Men say, that heav'n is perfect bliss

With dark-eyed maids to sport all day;

The juice of grape, I dare to say,

Is sweeter, and the cup to kiss.

Leave credit-joys to such as are

Thereby bemused, and as it comes

Seize thy cash-happiness; for drums

Make fairest music played afar.

Strategy for metaphor 1: literal translation

Strategy for metapghor 2: literal translation of the metaphor with meaning explained.

Strategy for metaphor 3: literal translation of the metaphor with meaning explained.

in qafele o mr ajab migo zarad!

daryāb dami ke bā tarab migo zarad!

Sāqi ghame farādye harifān che khori?

Pishār piāleh rā ke shab migozarad!

Metaphor: qafele omr

Literal translation: caravan of life

Meaning: passing of years and life

(FT):

One Moment in Annihilation's Waste,

One moment, of the Well of Life to taste-

The Stars are setting, and the Caravan

Starts for the dawn of Nothing--Oh, make haste!

Strategy for metaphor: literal translation plus addition of a new metaphor

(AT):

Alas, how wondrous suddenly

The caravan of life goes by:

'Tis well, this moment ere we die

To speed in happiness and glee.

Saki, why dreadest thou to-day

The resurrection's morn of fear?

Pass me the wine, while we are here;

The night is slipping fast away.

Strategy for metaphor: literal translation

ey del hame as bābe jahān hkāsteh gir

bāghe tarabat be sabze ārāsteh gir

vāngāh bar sare ān sabze shabi chon shabnam

benshaste va bāmdād bar khāste gir

Metaphor: bāghe tarabat

Literal translation: your garden of happiness

Meaning: happy times of your life

Simile: bar sare ān sabze shabi chon shabnam benshaste

Meaning: sit on the meadow like dew

(FT):

The Worldly Hope men set their Hearts upon

Turns Ashes--or it prospers; and anon,

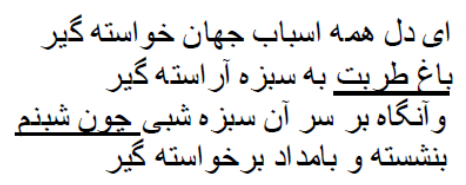


Like Snow upon the Desert's dusty Face,

Lighting a little hour or two--is gone.

Strategy for metaphor: omission

Strategy for simile: completely different simile

(AT):

Take it, my heart, all worldly ease

And longed-for joy is thine to hold;

Thy garden of delight untold,

Fringed round with meadows and green trees;

And take it, too, that one brief night

Like dew thou sittest on the mead,

But on the morrow, with all speed,

Shalt rise, and vanish out of sight.

Strategy for metaphor: literal translation

Strategy for simile: a new simile with change in meaning

har sabze ke bar kenār jūei raste ast

gūei ze labe fereshteh khūei raste ast

pā bar sare sabze tā be khāri nanahi

kān sabze ze khāk māhrūei raste ast

Simile: gūei ze labe fereshteh khūei raste ast

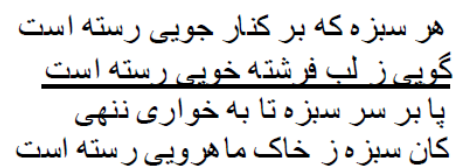

Meaning: it is like it has grown from the dust's of an angel mannered maid

(FT):

And this delightful Herb whose tender Green

Fledges the River's Lip on which we lean-

Ah, lean upon it lightly! for who knows

From what once lovely Lip it springs unseen!

Strategy for simile: translated literally with a metaphor

(AT):

O every grass so sweet and green

That springs beside the purling stream

Is the soft down, as it doth seem,

Of buried beauty, once serene.

Tread not with so indifferent care

Upon the meadow; for alas!

Where now thy foot is pressed on grass

Lie rosy cheeks of maidens fair.

Strategy for simile: literally translated with a metaphor

hengāme sabūh ay sanam farrokh pay

bar sāz tarāneh-o pish āvar may

kafkand bekhāk sad hezārān jam -o kay

in āmadan Tir mah o raftan Day

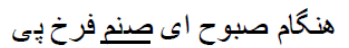

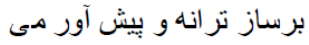

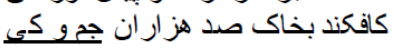

اين آمدن تير مه هران رفتن دي

Metaphor1: sanam

Literal translation: idol

Meaning: beloved

Metaphor 2: Jam o kay

Literal translation: Jamshid and keikhosro = two Persian kings

Meaning: powerful men, kings

Metaphor 3: amadane Tir mah o raftane Day

Literal translation: the bcoming of Tir month (first month of summer in Persian calendar) and passins of Dei month

(first month of winter in persian calendar).

(FT):

For "IS" and "IS-NOT" though with Rule and Line,

And, "UP-AND-DOWN" without, I could define,

I yet in all I only cared to know,

Was never deep in anything but--Wine.

This translation is a completely different poem

Strategy for metaphor 1: omission

Strategy for metaphor 2: omission

Strategy for metaphor 3: omission

(AT):

'Tis time to quaff the morning cup: 
My lucky-footed lad, arise !

Play music to the rosy skies

And bring the bowl, and fill it up.

A hundred thousand such as those

Famed tyrants who have swayed the earth

In burning June were brought to birth

And buried by December's snows

Strategy for metaphor 1: translation of wrong meaning

Strategy for metaphor 2: meaning has been translated without retaining the metaphor

Strategy for metaphor3: metaphor has been translated with a new metaphor with the same meaning as rāre azal rā na to dāni va na man

vin halle mo'ammā na to dāni va na man

hast az pase parde goftogūye man-o- to

chon parde baroftad na to māni va na man

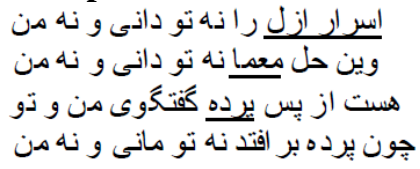

Metaphor 1: asrāre azal

Literal translation: the mysteries of the time without a beginning

Meaning: the mystery of creation and birth and death

Metaphor 2: mo'ammā

Literal translation: riddle

Meaning; mystery of creation and birth and death

Metaphor 3: parde

Literal translation: curtain

Meaning: the unknown mystery of creation and birth and death

(FT):

There was a Door to which I found no Key:

There was a Veil past which I could not see:

Some little Talk awhile of ME and THEE

There seemed--and then no more of THEE and ME

Strategy for metaphor 1: metaphor has been translated with a new metaphor with the same meaning

Strategy for metaphor 2: omission

Strategy for metaphor 3: literal translation

(AT):

The secrets of Eternity

Are far beyond our finite ken:

We cannot riddle what the Pen

Of Fate has scribed for you and me.

In casual converse we engage

Behind the curtain of our day;

But when the curtain falls, the play

Is done, and desolate the stage.

Strategy for metaphor 1: literal translation

Strategy for metaphor 2: literal translation

Strategy for metaphor 3: literal translation

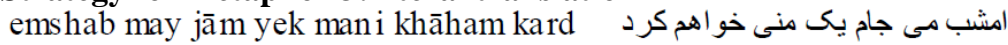

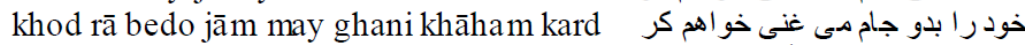

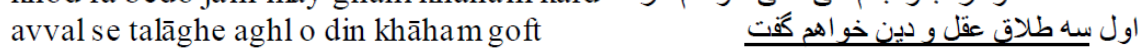

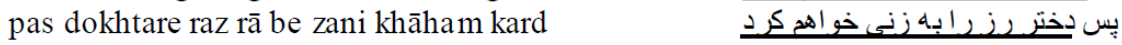

Metaphor 1: se talāghe aghl o din khāham goft

Literal translation: I will divorce religion and reason thrice

Meaning: I will abandon faith and reason completely

Metaphor 2: dokhtare raz rā be zani khāham kard

Literal translation: I will marry the daughter of wine

Meaning: I will drink a lot of wine

(FT):

You know, my Friends, how long since in my House

For a new Marriage I did make Carouse:

Divorced old barren Reason from my Bed,

And took the Daughter of the Vine to Spouse.

Strategy for metaphor 1: partial literal translation

Strategy for metaphor 2: literal translation

(AT): 
Now with a glass one measure high

Grief I will slay, old foe of mine

And, having quaffed two pints of wine,

Count no man half as rich as I.

First, in divorce thrice over cried,

Reason and Faith I'll put away,

Then take, to crown my happy day,

The daughter of the grape for bride

Strategy for metaphor 1: literal translation of metaphor with meaning explained

Strategy for metaphor 2: literal translation of the metaphor with addition of another metaphor

ay kash ke jāye āramidan būdi

yā in rahe dūr rā residan būdi

kāsh az pay sad hezār sāl az del khāk

chon sabze o mide bar damidan būdi

Simile: chon sabze omide bar damidan būdi

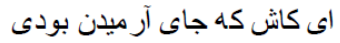

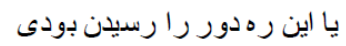

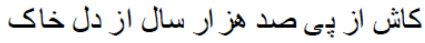

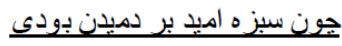

Literal translation: like grass there was a hope of spring again

Meaning: to be become alive again after death

(FT):

Would but the Desert of the Fountain yield

One glimpse - if dimly, yet indeed, reveal'd,

To which the fainting Traveler might spring,

As springs the trampled herbage of the field!

Strategy for simile: Literal translation with addition of some words

(AT):

Ah, would there were a little space

Where I might lay me down in peace,

That my far journeying should cease

At some sequestered resting-place:

And, as a thousand ages pass,

There might be hope from the dark earth

In a new miracle of birth

To spring again, like summer's grass

Strategy for simile: literal translation

gadrūn negari ze ghade farsūde māst

Jeyhūn asari ze ashke palūdeye māst

dūzakh sharari ze ranje bihūdeye māst

ferdaws dami ze vaghte asūdeye māst

كردون نكرى ز قد فرسدوده ماست

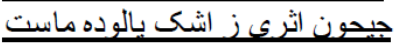

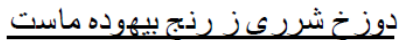

فردوس دمى زون وقت آسوده ماست ماست

Metaphor 1: gadrūn negari ze ghade farsūde māst

Literal translation: the Heavens are a vision of our weary body

Meaning: what people call Heavens is in fact the passage of time and wearing of our body

Metaphor 2 Jeyhūn asari ze ashke palūdeye māst

Literal translation: Oxus is a mark of our fine tear

Meaning: what people call Oxus is in fact a mark of our tear

Metaphor 3: dūzakh sharari ze ranje bihūdeye māst

Literal translation: Hell is a spark of our useless agony

Meaning: what people call hell is in fact those moments which we suffer

Metaphor 4: ferdaws dami ze vaghte asūdeye māst

Literal translation: Paradise is a moment of our ease

Meaning: what people call paradise, is in fact those moments which we are at ease

(FT):

Heav'n but the Vision of fulfill'd Desire,

And Hell the Shadow from a Soul on fire,

Cast on the Darkness into which Ourselves,

So late emerged from, shall so soon expire.

Strategy for metaphor 1: omission

Strategy for metaphor 2: omission

Strategy for metaphor 3: literal translation

Strategy for metaphor 4: literal translation

(AT):

The Heavens are girdle bound 
About my shrunk and weary thighs;

A trickle from my tea-stained eyes

Great Oxus, surging o'er the ground

Hell is a spark that upward spires

Out of my unavailing sigh,

And Paradise, a moment I

Am easy with my heart's desires

Strategy for metaphor 1: literal translation

Strategy for metaphor 2; literal translation

Strategy for metaphor 3: literal translation

Strategy for metaphor 4: literal translation

dar kargah kūzegari raftam dūsh

didam do hezār kū ze gūyā va kha mūsh

nāgāh yeki kūze barāvard khorūsh

در كار كَه كوزه كَرى رفتتر دوش

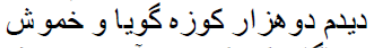

ناكاه يكى كوزه بر بر آورد خروش

ku kūze gar-o kūze khar-o kūze forūsh?

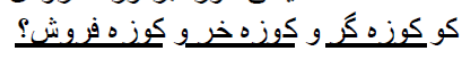

Metaphor 1: kūze gar

Literal translation: potter

Meaning: the jug which has been made of the potter's body

Metaphor 2: kūze khar

Literal translation: jug buyer

Meaning: the jug which has been made of the jug buyer's body

Metaphor3: kūze forūsh

Literal translation: jug seller

Meaning: the jug which has been made of the jug seller's body

(FT):

Whereat some one of the loquacious Lot-

I think a Sufi pipkin - waxing hot-

"All this of Pot and Potter-Tell me then,

Who is the Potter, pray, and who the Pot?"

Strategy for metaphor 1: literal translation

Strategy for metaphor 2: literal translation

Strategy for metaphor 3: literal translation

(AT):

Last evening in the potter's store

Two thousand heads I counted, each

A pot, some gifted still with speech,

Some fallen silent evermore.

And suddenly one pot, more bold,

Lifted his voice upon the air:

"Where is the potter now, and where

Are they that bought, and they that sold?"

Strategy for metaphor 1: literal translation

Strategy for metaphor 2: literal translation

Strategy for metaphor 3: literal translation

afsūs ke sarmāye ze kaf birūn shod

vaz dast ajal basi jegarhā khūn shod

kas nāmad az ān jahan ke porsamaz vay

kahvāl mosāferān donyā chūn shod

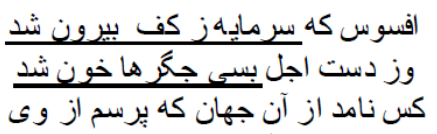

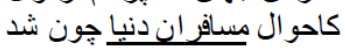

Metaphor 1: sarmāye ze kaf birūn shod

Literal translation: asset went away from the hand

Meaning: the years of life passed

Metaphor 2: basi jegarhā khūn shod

Literal translations: many livers became blood

Meaning: many people were agonized

Metaphor 3: mosāferān donyā

Literal translation: passengers of the world

Meaning: the dead people

(FT):

Strange, is it not? that of the myriads who

Before us pass'd the door of Darkness through, 
Not one returns to tell us of the Road,

Which to discover we must travel too.

Strategy for metaphor 1: omission

Strategy for metaphor 2: omission

Strategy for metaphor 3: meaning has been translated with addition of another metaphor

(AT):

Ah, life's precious capital

Was spilled so soon and drained away,

That Destiny in ambush lay

For many hearts, to slay them all:

And, for the world that after waits,

No man has ever come from there

To bring us tidings, how they fare

Whose journey lies beyond its gates.

Strategy for metaphor 1: literal translation

Strategy for metaphor 2: metaphor has been translated with a new metaphor with the same meaning

Strategy for metaphor 3: literal translation

bar kū ze gari parir kardam gozari

az khāk hami nemūd har dam honari

man didam agar nadid har basari

khāke pedaram dar kafe har kūzegary

Metaphor: khāke pedaram dar kafe har kūzegary

Literal translation: the clay of my father in the hand of every pottery

Meaning: our body becomes dust and will be used as dust by other generations

(FT):

Listen again. One Evening at the Close

Of Ramazan, ere the better Moon arose,

In that old Potter's Shop I stood alone

With the clay Population round in Rows.

Strategy for metaphor: omission

(AT):

As I was passing yesterday

Where potters play their skilful trade

I watched amazed, as each displayed

His cunning with the pliant clay

And I behold, as scarce I trust

They see who lack the gift of sight,

Those bowls they shaped for our delight

Where moulded from our father's dust.

Strategy for metaphor: meaning has been translated without retaining the metaphor

ay rafte be chogāne ghazā hamchon gū

chap mikhorad o rāst miravad hich magū

kānkas ke torā fekandeh andar tako pū

oū danado oū danado oū danado oū

Simile: ay rafte be chogāne ghazā hamchon gū

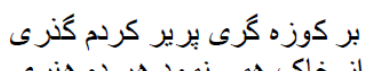

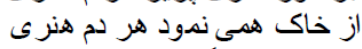

من ديدم اكر نديد هر هر بصرى هنرى

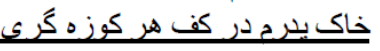

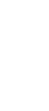


Thy ball and mine to spin to-day,

He knows the game, he knows, he knows!

Strategy for simile: literal translation

zenhār ze jāme may marā qūt konid vin chehre kahrobā cho yāghūt konid chon mordeh shavam bebāde shū'id marā vaz chūb razam takhteye tābūt konid Simile: vin chehre kahrobā cho yāghūt konid

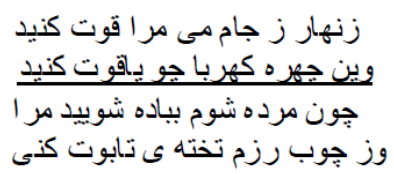

Literal translation: and make this amber-colored face red like ruby

Meaning: change the color of my face to red

(FT):

Ah, with the Grape my fading Life provide,

And wash my Body whence the life has died,

And in a Windingsheet of Vine-leaf wrapt,

So bury me by some sweet Garden-side.

\section{Strategy for simile: omission}

(AT):

Oh let me with good wine be fed-

My dear companions, do not fail!-

Until my cheeks, now amber-pale,

Be changed to rubies, rich and red.

And when I die, as die I must,

Wash my cold body all with wine;

Carve me the timber of the vine

For coffin, to preserve my dust

Strategy for simile: simile has been translated by a metaphor

yārān cho be ettefāq mi'ād konid

khod rā bejamāl yekdegar shād konid

sāqi cho may moqāne dar kaf girad

bichāre folān rā bedo'ā yād konid

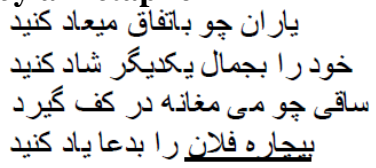

Metaphor: bichāre folān

Literal translation: the poor fellow

Meaning: Khayyam

(FT):

And when Thyself with shining Foot shall pass

Among the Guests Star-scatter'd on The Grass,

And in Thy joyous Errand reach the Spot

Where I made one--turn down an empty Glass!

Strategy for metaphor: meaning has been translated without retaining the metaphor (AT):

When ye are met in harmony,

Beloved friend, in after days,

And on each other's beauty gaze,

And are rejoiced by what ye see;

And when the saki, standing there,

Takes in his hand Magian wine,

Think on the anguish that is mine

And $\mathrm{O}$, recall $\underline{\mathrm{me}}$ in prayer.

Strategy for metaphor: meaning has been translated without retaining the metaphor

bā to bekharābāt agar gūyam rāz

بانو بخر ابات اكر كويم ر از باز

beh zānkeh bemehrāb konam rāzo niāz

ay aval o ay ākhare khalghān hame to

khāhi to marā besūz khāhi benavāz

Metaphor 1: ay aval o ay ākhare khalghān hame to

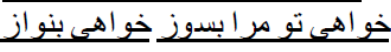

Literal translation: oh the One Who is the First and the Last of all people

Meaning: Oh God, Who create and make us all die

Metaphor 2: khāhi to marā besūz

Literal translation: burn me if you want

Meaning: put me in the Hell in Doomsday if you want

Metaphor 3: khāhi benavāz 
Literal translation: caress me if you want

Meaning: put me in paradise in Doomsday if you want

(FT):

And this I know: whether the one True Light,

Kindle to Love, or Wrath consume me quite,

One Glimpse of It within the Tavern caught

Better than in the Temple lost outright.

Strategy for metaphor 1: omission

Strategy for metaphor 2: metaphor has been translated with a new metaphor with the same meaning

Strategy for metaphor 3: metaphor has been translated with a new metaphor with the same meaning

(AT):

Better tavern, and with wine

To lay Thee all my secrets bare,

Than to intone the parrot prayer

And thou not with me, in the shrine

Thy Name is last and first to tell;

Whatever is, save thee, is nil;

Then cherish me, if so Thy Will

Be done-or burn my soul in Hell!

Strategy for metaphor 1: meaning translated without retaining the metaphor (based on translator's interpretation of the meaning).

Strategy for metaphor 2: meaning has been translated without retaining the metaphor

Strategy for metaphor 3: meaning translated without retaining the metaphor

vaghte sahar ast khiz ay māyeye nāz

narm narmak bādeh khoro chang navāz

kānha ke bejāyand napāyand basi

vānhā ke shodand kas nemiayad bāz

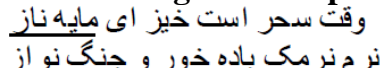

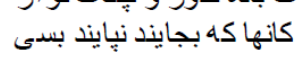

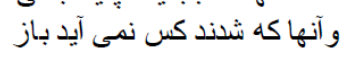

Metaphor: māyeye nāz

Literal translation: the cause of beauty and sweetness

Meaning: beloved

(FT):

And, as the Cock crew, those who stood before

The Tavern shouted-"Open then the Door.

You know how little while we have to stay,

And, once departed, may return no more."

Strategy for metaphor: omission

(AT):

It is the time of dawn: upspring,

Sweet beauty delicately fine,

And slowly, slowly sip the wine,

And sweep the lute's melodious string.

For all now sojourning on Earth

Noy long, not ever shall abide;

And of the others, who have died,

Not one shall come again to birth.

Strategy for metaphor: meaning has been translated without retaining the metaphor

TABLE 4.1

STRATEGIES EMPLOYED BY EACH TRANSLATOR IN TRANSLATING METAPHORS

\begin{tabular}{|l|l|l|l|l|}
\hline \multicolumn{2}{|l|}{ Arberry's translation } & Fitzgerald's translation & total & \\
\hline Different metaphor with same meaning & 11 & 8 & 19 & \\
\hline Literal translation (keeping the metaphor) & 37 & 17 & 54 & \\
\hline $\begin{array}{l}\text { Literal translation+ } \\
\text { meaning explained }\end{array}$ & 8 & 1 & 9 & \\
\hline Meaning translated without metaphor & 10 & 11 & 21 & \\
\hline Tr. by a metaphor with different meaning & 0 & 2 & 2 & \\
\hline Omission & 0 & 27 & 27 & \\
\hline Wrong meaning translated & 1 & 0 & 1 & 3 \\
\hline Literal translation + addition of another metaphor & 2 & 1 & 2 & \\
\hline Partial literal translation & 0 & 2 & 2 & 138 \\
\hline Total & 69 & 69 & & \\
\hline
\end{tabular}


TABLE 4.2

STRATEGIES EMPLOYED BY EACH TRANSLATOR IN TRANSLATING METAPHORS

\begin{tabular}{|l|l|l|l|}
\hline & Arberry's translation & FitzGerald's translation & Total \\
\hline Literal translation & 3 & 0 & 3 \\
\hline $\begin{array}{l}\text { Translated literally } \\
\text { with metaphor }\end{array}$ & 2 & 2 & 4 \\
\hline $\begin{array}{l}\text { Tr. with different simile with different } \\
\text { meaning }\end{array}$ & 1 & 1 & 2 \\
\hline Omission & 0 & 1 & 1 \\
\hline $\begin{array}{l}\text { Meaning without } \\
\text { Simile }\end{array}$ & 0 & 1 & 1 \\
\hline $\begin{array}{l}\text { Literal translation plus addition of } \\
\text { some words }\end{array}$ & 0 & 1 & 1 \\
\hline Total & 6 & 6 & 12 \\
\hline
\end{tabular}

\section{CONCLUSION}

This study was done in order to find the strategies employed by translators of Khayyam in translating the metaphors and similes. Thirty-five Rubais were found which contained either simile or metaphor or both and were translated by both Arberry and FitzGerald. It should be noted that some of the Fitzgerald's translation cannot be matched with their original texts because they are completely different. Nine strategies were found which had been used by the translators in translating the metaphors which are: literal translation, different metaphor with the same meaning, literal translation of the metaphor plus meaning explained, meaning translated without keeping the metaphor, translation by a metaphor with different meaning, translation of the wrong meaning, omission of the metaphor, literal translation plus addition of another metaphor and partial literal translation. Arberry has used seven strategies and Fitzgerald eight strategies. It cannot be said that the strategies used were all deliberate by the translator.

Khayyam has used few similes in his poems. In this analysis six were found which had both been translated and six strategies were employed by the translator. Those strategies are: literal translation, translation with a metaphor, translation with different simile with different meaning, omission, translation of meaning without retaining the simile, literal translation plus addition of some words

Since the translators have better translated metaphors we can conclude Arberry has translated metaphors better due to several reasons, an some of them are as follows:

1. Arberry has omitted none of the metaphors but FitzGerald has omitted 27 of the metaphors

2. Arberry has used 37 literal translation of the original metaphors but FitzGerald has used 17

3. Arberry has been more creative and has created 11 metaphors with same meaning but FitzGerald has only created 8

So Arberry has been more successful in his translation and transferred the metaphors and their meaning more successfully.

As for similes, though they are slightly similar but again we can say that Arberry has translated them better due to following reasons:

1. Arberry has translated 3 of them literally but FitzGerald has only translated one of the similes literally and he has added some other words to it.

2. Arberry has not omitted any of the similes in the translation but FitzGerald has omitted one.

\section{REFERENCES}

[1] Abrams, M.H. (1999). A Glossary of Literary Terms. Boston: Earl McPeek.

[2] Bloom, H. (ed). (2004). Edward FitzGerald's The Rubait of Omar Khayyam. Broomall: Chelsea House Publishers.

[3] Catford, J. C. (1965). A Linguistic Theory of Translation. London: Oxford University press.

[4] House, J. (2000). "Consciousness and the Strategic Use of Aids in Translation”. Tirkkonen-Condit Sonja \& Riitta Jaaskelainen (eds): Tapping and Mapping the Processes of Translation and Interpreting, J. Benjamins.

[5] Karlin, D.(ed). (2009). Rubaiyat of Omar Khayyam. New York: Oxford University Press.

[6] Kiraly, D. (1995). Pathways to Translation. Ohio: Kent University Press.

[7] Larson, M.L. (1984). Meaning-based Translation: A guide to cross-language equivalence, Lanham, New York \& London: University Press of America.

[8] Newmark, Peter. (1981). Approaches to Translation, Oxford: Pergamon Press.

[9] Séguinot C. (1997). "Accounting for variability in translation”. J. Danks, G.M. Shreve, S. B. Fountain and M. K. McBeath (eds.). Cognitive Processes in Translation and Interpreting, Sage Publications, London

[10] Tirkkonen-Condit, S. (2000). "Uncertainty in translation processes". Tapping and Mapping the Process of Translation: Outlooks on Empirical Research, S. Tirkkonen-Condit, and R. Jääskeläinen, (eds.). Amsterdam and Philadelphia: John Benjamins.

[11] Wilss, W. (1996). Knowledge and Skills in Translator Behavior. Amsterdam: John Benjamins.

[12] Zare-Behtash, E. (1994). FitzGerald's Rubaiyat: A Victorian Invention (Doctoral Dissertation, Australian National University, Canberra, Australia). Retrieved from http://thesis.anu.au/uploads/approvrd/adt-ANU20010824.152643/public/02whole.pdf 
Morteza Zohdi is currently a lecturer of English language and linguistics at university of Applied Science and Technology, Center 18, Tehran, Iran. He has been engaged in teaching English language for more than five years. He holds M.A in Translation studies, B.A in Translation Studies. He has published a number research projects and articles in his area of interest in academic journals.

Ali Asghar Rostami Abu Saeedi is currently Associate Professor of English Language and Literature at University of Sistan and Baluchestan, Zahedan, Iran. He has been engaged in teaching English language and linguistics for more than twenty year. He holds Ph.D. in English Language and Literature from Liverpool University, M.A. in linguistics and B.A. in English language. He has published a number research project and articles in his area of interest in academic journals. He has editor of some scientific journals. 